\title{
Dystopian Narrative in Gundala's Multiverse: Transmedia Studies
}

\author{
Irish Hening $^{1}$, Suma Riella Rusdiarti ${ }^{2}$ \\ \{irishhening27@gmail.com \} \\ Postgraduate of Literature, Faculty of Humanities, Universitas Indonesia 57126, Indonesia
}

\begin{abstract}
The depiction of the dystopian world in a literary work within the superhero's genre has been widely used by famous literary works worldwide. Dystopia describes a catastrophic picture of life; this is inversely to the world of utopia which describes an ideal world. In 2019, superhero Gundala was recreated to its new adaptation story. In this case, Gundala was published in the online comic Gundala: The Son of Lightning and the printed comic Gundala: Takdir which also a complementary work from the movie Gundala: Negeri ini Butuh Patriot. These three media are integrated as a work of transmedia, but they have a different universe (multiverse). Even though they have different universes, there is one similarity between them which is the developing of dytopian narration. It could be seen from the government and authority's control, social crisis, poverty and pessimism which also affect the building of characters, namely Sancaka (the superhero) and Pengkor (the villain). Using Henry Jenkins' transmedia storytelling theory and Keith Booker's dystopian theory, this paper will expose the Gundala's transmedia which using the dystopian narrative as a background to create the needs of superheroes.
\end{abstract}

Keywords: transmedia studies, Gundala, dystopian narrative, multiverse

\section{Introduction}

The dystopian narrative has become a trend which being used in cultural and literary products. [1] Booker reveals that literary works from Russia and Germany during the World War presented many dystopian conditions resulting from the social and political turmoil in these countries. [2] These literary works became a medium to criticize the conditions at that time. In subsequent developments, the theme of dystopia was present in various other cultural products such as comics and movie with the superhero's genre. The story of the superhero Batman from DC which is very deeply, describing the dystopian world in its narrative. Marvel also through the comics and movie Avengers: Civil War also presents the world of dystopia regarding the storyline which dealing with the Superhuman Registration Act, especially "Dark Reign" in which the supervillains are placed in positions of power.

Brundige also stated that the cultural and literary products with the superhero's genre from Marvel and DC also apply a narrative synergy through various forms of media to build a universe of superheroes. [3] Marvel and DC have created a new narrative experience for their superheroes characters through various media, such as printed comics, graphic novels, movie, animation, TV series, merchandise and various media with different narratives that are interrelated. [4] This phenomenon is referred to as an effort to implement transmedia storytelling as Jenkins states that this is a process where integral elements of a fiction are systematically spread across various media to create integrated and coordinated entertainment. Each of these 
media has a different world of stories to form one universe. However, these superheroes genres also often build more than one universe about one character. Batman and Flash are the examples of multiple universes which known as the multiverse [5] [6].

The success of Marvel and DC in the superheroes genre certainly has an effect on other creators in the world. Indonesia itself has recently attempted to establish a production house applying the transmedia. Bumilangit production house is making efforts to create a synergy for transmedia such as Marvel and DC. [7] As an initial step in building a transmedia project, Bumilangit released the Gundala movie and comic in 2019 which was a re-adaptation of the Gundala story by Hasmi (1969). The movie Gundala: This Country Needs Patriots was a big breakthrough in the marketing of this project.

Before to the release of the movie, Bumilangit also published the figure of Gundala in online comic Gundala: Son of Lightning which published through the platform of online comics Webtoon. Bumilangit also issued a printed comic adaptation of the movie with the title The Official Movie Adaptation Gundala: Takdir. [8] [9] Each story which displayed in the movie, online and printed comics carries different narratives. Even the universe between the movie and the online comic are different. Both of them have their own universe. But despite the difference of universe, the distribution of the movie and the comics has the same depiction of the sociopolitical conditions in Jakarta. Critics of the socio-political conditions in Jakarta today are presented through the conflicts that occur in the movie and comics. The social inequality, poverty, the spread of hoaxes, corruption and nepotism are to be found in this transmedia work. These bad conditions of reality characterize a dystopian world (the antonym for utopia).

Regarding the efforts to spread the narrative of the superhero genre with the transmedia technique, previous studies have discussed the transmediality of superhero-themed works in Marvel and Bumilangit works. Jeffries has conducted research on this Marvel work. Jeffries' research illustrates that Thor, who is part of the Marvel Cinematic Universe, has appeared in the media of movie and comics. Using Saint-Gelais' transfixional concept, his research shows that the MCU is defined as an intertextual relationship that uses the source text arrangement as if they existed independently. [10] Research related to the Bumilangit production house as Indonesian Intellectual Property which implements transmedia storytelling has also been carried out by Ina Listyani Riyanto (2019) with a focus on the Gundala story as part of the Bumilangit Universe.

Through his research, Riyanto explained the distribution of narratives in each of the Bumilangit production media which are interrelated with one another to build one story world and universe. [11] While research on dystopia has been done by Cortiel, he explains that this essay argues that Frank Miller's Batman: The Dark Knight Returns (1986) and Batman: The Dark Knight Strikes Again (2001-2002) are grounded in a specific type of anticipatory consciousness that we read as risk consciousness. He has identified three levels of risk representation of dystopian world in the two graphic narratives which are the apocalyptic riskscapes, individual risk-taking as edgework, and the staging of global risk in the media. [12]

Based on previous studies, no one has discussed specifically the dystopian narrative which appears in the Gundala multiverse as a transmedia work. Therefore, this study intends to unwrap the Indonesian dystopian narrative represented through the city of Jakarta and its impact to the characters in Gundala's transmedia. 


\section{Research Methods}

In this study, the authors use a qualitative approach. The authors collect data from printed and online sources, such as books, journals and trusted websites. Through analysis-related sources, the authors are able to analyse the structure of the text using Henry Jenkins' Transmedia Storytelling and uncover the dystopian narrative in the text based on the dystopian concept from M. Keith Booker. The first theory which would be used is Transmedia Storytelling. The term transmedia which known as the distribution of stories in various media which was first introduced by Henry Jenkins. In the adaptation study, Jenkins states that transmedia is a structured relationship between several different media platforms. In practice, it is related to works of fiction.

However, nowadays the producers of fiction works have also implemented this narrative technique with all the needed media by taking advantages of all these media to reach its target. Jenkins also introduced the concept of transmedia storytelling. This concept is the art of creating a large world from a fictional world with rich full diversity. In addition, Jenkins says that transmedia storytelling is a process in which an integral element of a fiction is systematically spread across various media to create integrated and coordinated entertainment. Ideally, each media makes a unique contribution to the story development. Based on these details, transmedia storytelling can be defined as an effort to create a story world and transfer all its elements such as stories, adventures, characters, spaces, and culture, both 'online' and 'offline' from all types of media.

In this case, in the world of transmedia there is more than one narrative. Each narrative, as part of a puzzle or piece of the big picture has a contribution to the whole. Each narration has a separate story and is part of a larger story. [13] The other theory which used is from Booker (1994). He said that the word dystopia was first conveyed by John Stuart Mill in 1868 when he criticized the Irland government for the land policy at that time. Dystopia means a bad place and conditions when society is suffering. This term is a condition that is opposite to the utopia which describes a perfect and optimistic society. The word utopia itself also appeared earlier in 1516 by Thomas More in his book Utopia to describe a fictional island as a satire against the British state.

There are some characteristics of dystopian fiction stories: the government control, environmental damage, power control, survival and the individualism. Booker (1994) says that in dystopian fiction, usually the government will not tolerate the differences by persecuting certain marginalized groups. In addition, Booker (1994) also adds that dystopian fiction works usually have a time and place background that is far from the author, even though the social issues raised relevant to every century [14].

\section{Results and Discussion}

\subsection{Control and Power in Gundala's Dystopian World}

Almost all the works with the theme of dystopia describe the government and the authority who have absolute power: oppressive and domineering, also controlling all spheres of life. This condition greatly affects all levels of society and regulates people's actions and thoughts. In order to maintain their power over people's lives, society is organized into a life with full of fear. The depiction of the dystopian narrative is very clearly depicted in the distribution of the Gundala text in three media: movie, printed comic and online comic. Movie and printed comics 
exist in the same story world and universe. In the movie, the audience is given the opportunity to know the depiction of the dystopian world where the main character and the people of Jakarta have had to deal with this in a long period of time. The audience understands this storyline from Sancaka's point of view, who is the main character and superhero in the Gundala story. Also in this movie, the dystopian narrative influences the characters's development of Sancaka and Pengkor.

However, fans will better understand the influence of the dystopian narrative on the Pengkor's character in the printed comic. It happens because the reader is given an opportunity to understand the new perspective from Pengkor's point of view as the villain. This alternative retelling from a different point of view is an effort to form transmedia's work related to world building. In this context, the printed comic acts as a complementary medium for the movie. The next interesting thing is the presence of online comics, which has different storyline and characters from the printed comics and Gundala movie. The main character who is presented is still Sancaka with different looks and backgrounds, but Pengkor only appeared at the end of the story.

This villain character is not really displayed in the Gundala universe in this online comic because Sancaka had to deal with other villain. However, despite having a different story world and universe, the online comic Gundala still carries a dystopian narrative. In these three media which will be analyzed, the depicted dystopian narrative is about the existence of social crises, riots, poverty and pessimism. These things happen because the government acts arbitrarily and is indifferent to the situation in society and also the control of the mafia and the strong capital owners.The socio-political issues which are presented in the Gundala transmedia seemed to provide the background for the story that made a dystopian condition possible. Poverty and social inequality are the issues which most frequently expressed, but the power of government authority is also shown very clearly in every media. The problems of life in the city of Jakarta are an opening to build a universe from Gundala's transmedia. In the Gundala's printed comic, readers can find various narratives of the government's depravity from the start of the election for new legislative councils that carried out acts of collusion.

This was done by the chairman of the legislative council and the leader of the big mafia named Pengkor. The chairman of the council as a government person has collaborated with Pengkor to win the hearts of the people to choose him again as the chairman. These two people who have social capital and symbolic power work together to maintain their power and further outwit the lower classes.

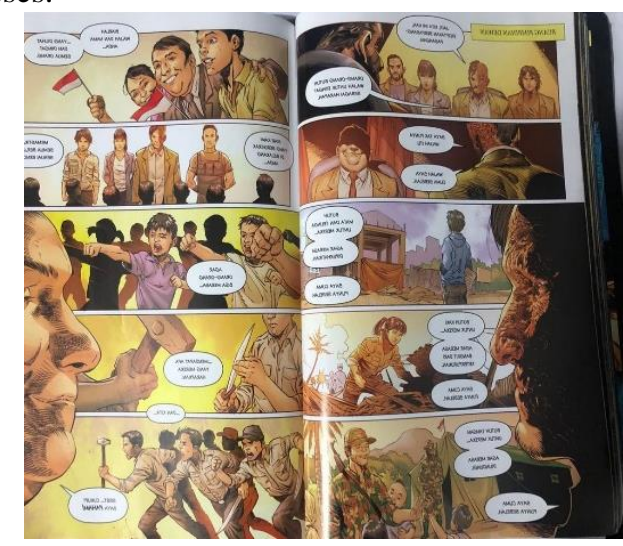

Fig 1. The Meeting of Chairman of Council and Pengkor 
Even though the online comic has a different universe from the Gundala narrative in movie and printed comics, Gundala's online comic also provide a depiction of the depravity and power of the government that torments its people. The government is considered to have committed corruption, causing the lower-class people to suffer even more. This was used as an opportunity by villain figure Dwara to overthrow the government in the interests of his own power. This poor condition of society is presented in the online comic text Gundala chapter 2 with the narrative of a conversation between Dwara and a father who is holding his child. "Our family has only been able to eat rat meat for a month, Mr. Dwara ... Now our child has colitis and is difficult to cure."

Through this character's expression, readers can understand how difficult it is for the lower class to survive in the city of Jakarta due to an arbitrary government. These lower classes should receive basic food donation from the government, but they do not get it because the government is corrupt. The poverty causes them have lack of money to even buy nutritious food
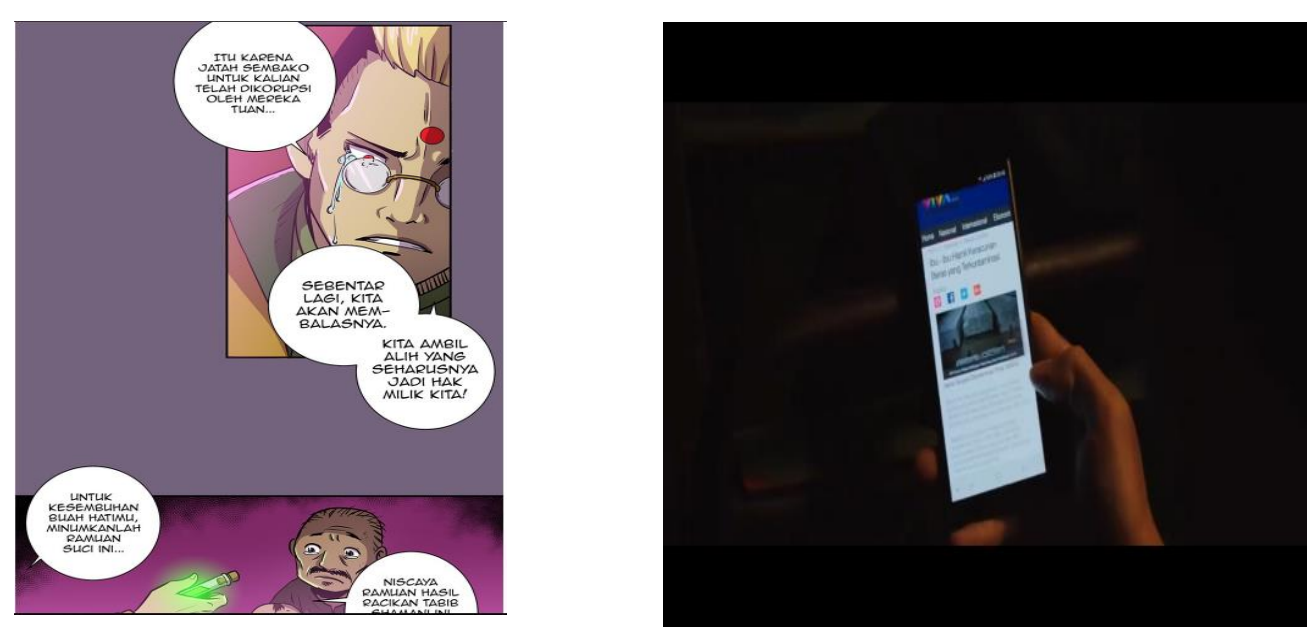

Fig 2. Dwara and the Poor and The Spreading of Hoaxes

In the movie, Pengkor is trying to worsen the situation in Jakarta by spreading mass panic through hoaxes. He already commanded his workers to poison the rice which would affect the pregnant women. The public immediately panicked and on this occasion and he intensified his plans by spreading hoaxes. The riots and chaos that are happening make it easier for hoaxes to spread among the public. In the movie, the public can easily get information from news and social media on their cellphones. This caused the spread of hoaxes to take place very quickly and caused public panic and hysteria. The case of hoax spreading when it is related to the current condition of Indonesia is a case that often occurs.

Transmedia Gundala seems to be trying to present the latest social issues so that spectacles can get more into the world of stories (immerse). The printed comic media Gundala as a complementary work of the movie also contributes to the context of hoaxes that are displayed in the movie. In this printed comic provides a news corner which explains the current situation in society. A rubric regarding the spread of hoaxes is featured in this printed comic. This is one of Transmedia's efforts to create a more complete and structured world building. 


\subsection{Child's of Dystopian World : Pengkor and Sancaka}

In transmedia Gundala, which is spread across three media, the main character who becomes the superhero is Sancaka and the main villain is Pengkor. Even though online comic has a different universe from the printed comic and the movie, these two characters are still present in each of these media. The story of Sancaka and Pengkor's life from their childhood to adulthood living in this dystopian world is described clearly in the printed comic. These two figures are like both sides of a coin which is very interesting to discuss. It is also necessary to discuss the social inequality that occurs in society which ultimately affects the perspective of these two figures and gives them a reason to become the villain and the superhero.

In the movie, social inequality is present at the beginning of the movie when Sancaka's father conducts a demonstration with workers to demand the increasing for labor wages. Factory owners who have strong position, can afford to pay a lot of security officers to fight the demonstration workers. Even with money, the factory owner also paid Sancaka's father's friend to become traitors which causing Sancaka's father died by being killed. Through this, it can be seen that in the power struggle, Sancaka's father, who has a relationship with his fellow workers, can be defeated by the strong ownership of economic capital owned by the factory owner.

Almost same with Sancaka, Pengkor should suffer because his family was killed by plantation workers who was provoked by one of the workers. Social inequality and poverty of the lower classes also triggers the workers to be provoked. This is not only described in the movie, but also in the printed comic Gundala. The vocalization that is presented in the printed comic is from the perspective of Pengkor. In this comic, readers can also see how social inequality has formed an innocent child who later became a big boss mafia who is respected and feared. The existence of a social class, namely the owners of capital and the workers, creates a conflict which is the root of the main narrative of this text. The conflict that occurred caused losses on both sides. Losses do not only occur to the poor, but also to the owners of capital. This can be seen in the scene where the Pengkor family are murdered by plantation workers who were anarchist.

But we should also see that power comes in the presence of a dominating party and a subordinate party. In essence, this is related to differences in the social class of society consisting of the upper class and the workers / laborers. These social classes create social inequalities between people and cause polemics in society to create chaos. In the movie and printed comic book adaptation of the movie, the narrative that is shown is exactly the same even though the storyline and the storyteller's point of view are different. The character of Sancaka is shown as a figure from the lower class or workers. Sancaka lives with a poor and simple family. Sancaka's father is a factory worker, and his mother is just a housewife.

Even so, the Sancaka family still provides Sancaka with a proper education. In the movie, Sancaka goes to school which means that he has obtained the cultural capital of education. The Sancaka family also supports Sancaka's ability to repair electronic devices. Sancaka's ability to repair is related to his hidden ability to control lightning. In Sancaka's life, there is no change in social class in the economic field. When Sancaka grew up he became a security guard at a publisher factory and opened a repair service.

This is different from Sancaka's opposition, Pengkor. Pengkor was born from among the capital class. His father owned the plantation and employed many workers. However, unlike Sancaka, Pengkor experienced fluctuating class changes. After the death of his father who was killed by his plantation workers, Pengkor was put in an orphanage. There, he joined other orphaned children and lived in misery because he was always tortured by the orphanage officers. 
At its peak, Pengkor who had good oratory skills had invited his friends at the orphanage to fight against the injustices that occurred in the orphanage by killing people who had tortured them. In the printed comic, it is also explained that after Pengkor left the orphanage he lived on the streets with the orphanage children and formed a new family on the streets with his friends. Together with his friends, he collects trash and used goods. Pengkor also continues to prioritize education for himself and his friends, which indicates that he still maintains cultural capital in his life. When he grew up, Pengkor returned to the top-class position again.

From the previous explanation, it can be seen that both Pengkor and Sancaka are the victims of social disparities in society. Sancaka's father died because he was murdered during a demonstration regarding the increase in labor wages. In the case of Sancaka's father, there were factory officials who had the highest power and had economic capital. At the second protest, Sancaka's father is betrayed and stabbed by his colleagues who have been bribed by the factory owner and died in Sancaka's arm. A year later, economic problems also affected Sancaka's life because Sancaka's mother went to another city to find work and never return.

Likewise, with Pengkor, his parents were killed by workers demonstrating for a salary increase. Conflicts between classes, namely between the owner and workers, in fact also have an impact that is not only detrimental to workers. In Sancaka's case, the victim fell to Sancaka's father who was a worker, in Pengkor's case, the victim fell to Pengkor's father, who was a capital owner. Through this, it can be seen that the war of positions between the people does not only cause casualties to workers, but capital owner can also become victims. All of these things occur as a result of high economic disparities between societies. The printed comic also shows that Sancaka was struck by lightning, while Pengkor was burned by fire. Both are fellow young children who experience the same dark period even though they come from different social classes.

However, even though they are both victims of this dystopian world, Sancaka and Pengkor have chosen a different way of life. In this point, the dystopian world is a background that shows the destruction in society. In this context, Pengkor who were disillusioned by the injustice in society chose to make the situation worse. He became a mafia who is feared by the public and wanted to worsen the existing dystopian world. This is different from Sancaka, who has experienced fluctuating character development. Sancaka also felt disappointed with the situation and chose to be ignorant, but in the end he wanted to make changes in society to escape this dystopian world. In this context, the dystopian narrative that is present in the Gundala text is a background that ultimately reinforces the presence of Gundala's figure as a superhero which we could also see in the tagline of the movie Gundala which is This Country Needs Patriots.

\section{Conclusion}

Dystopia work is a tool to criticize the prevailing socio-political system conditions. While utopian literature describes an ideal world, dystopian literature describes the flaws and failures of a society. The control of government power or the rulers has an important role in building a dystopian world narrative. The transmedia Gundala which also a multiverse text depicts contemporary dystopian conditions related to the situation in Jakarta. Transmedia Gundala seems to present a world that displays the control of government and rulers' power, the destruction of the surrounding environment and efforts to survive. The storyline in the movie and comics continues to depict the conditions of the poor who are oppressed and helpless due to worsening conditions. 
Another interesting thing is that both superhero and the villain are the victims of this dystopian world which has two contradicting life choices. However, this dystopian narrative is existed to strengthen the idea of the superheroes needs. At the end, the research about transmedia works still needs to be more explored. Hopefully, this research could help the next research regarding the transmedia work in Indonesian literary works.

\section{Acknowledgements}

I would like to express my gratitude to DRPM Universitas Indonesia, Depok, West Java which has given the opportunity to me to conduct this research with the support from Research Grant PUTI (Publikasi Terindeks Internasional) for Social-Humanities. My grateful also dedicated for Dr. Suma Riella Rusdiarti as the co-writer who has also given alot of suggestion for the perfection in this article. The last, this research is dedicated to Indonesian research in the field of transmedia studies which still growing.

\section{References}

[1] A. Burgess. Twentieth Century Dystopian Fiction. https://www.anthonyburgess.org/twentiethcentury-

[2] dystopian-fiction/, 2020.

[3] M. K. Booker. The Dystopian Impulse in Modern Literature: Fiction as Social Criticism. London: Greenwood Press, 1994.

[4] A. Brundige. The Rise of Marvel and DC's Transmedia Superheroes: Comic Book Adaptations, Fanboy

[5] Auteurs, and Guiding Fan Reception, 2015.

[6] R. Reynolds. 1992. Superheroes: A Modern Mythology. London: B.T. Batsford Ltd.

[7] H. Jenkins...TransmediaaStorytellinga202.a Accessed from the professional personal blog of Henry Jenkins

[8] http://henryjenkins.org/blog/2011/08/defining_transmedia_further_re.html, 2007.

[9] H. Jenkins...Transmedia Storytelling 101. Accessed from the professional personal blog of Henry Jenkins

[10] http://henryjenkins.org/blog/2007/03/transmedia_storytelling_101.html, 2007.

[11] Bumilangit. Official Website Bumilangit. Accessed through https://bumilangit.com/en/landing/

[12] Bumilangit. Bumilangit dan Koloni Meluncurkan Komik Gundala The Official Movie Adaptation. https://bumilangit.com/id/2019/09/10/bumilangit-dan-koloni-meluncurkan-komik-gundala-theofficial-movie-adaptation/

[13] Bumilangit. 'Gundala The Lightning Son' Comic is Now Available on Line Webtoon. https://bumilangit.com/en/2019/06/18/gundala-putra-petir-comic-now-available-on-line-webtoon/

[14] D. Jeffries. The Worlds Align: Media Convergence and Complementary Storyworlds in Marvel's Thor: The

[15] Dark World. In Boni M. (Ed.), World Building. Amsterdam: Amsterdam University Press, 2017.

[16] I. L. Riyanto. Transmedia Storytelling in Indonesian Intellectual Property. Prosiding dalam ICADECS 2019 (International Conference on Art, Design, Education and Cultural Studies). Malang: Universitas Negeri Malang, 2019.

[17] Cortiel and L. Oehme. The Dark Knight's Dystopian Vision: Batman, Risk, and American Nation, 2015.

[18] H. Jenkins, H. Cultural Logic of Media Convergence. Di dalam International Journal of Cultural Studies edisi 7, 2004.

[19] M. K. Booker. Dystopian literature: a theory and research guide. Westport, Conn, Greenwood Press, 1994V. Thersia, M. Arifuddin, and M. Misbah, "Meningkatkan Kemampuan Pemecahan Masalah Melalui Pendekatan Somatis Auditori Visual Intelektual (SAVI) dengan Model Pengajaran Langsung,” Berk. Ilm. Pendidik. Fis., vol. 7, no. 1, p. 19, 2019, doi: 10.20527/bipf.v7i1.5638. 